\title{
STRATEGI PEMBELAJARAN KARAKTER KERJA KERAS
}

\author{
Ismail Marzuki \\ ismailmarzuki@umt.ac.id \\ Lukmanul Hakim \\ lukman@umt.ac.id \\ (Dosen Fakultas Agama Islam Universitas Muhammadiyah Tangerang)
}

\begin{abstract}
Abstrak:
Pendidikan menjadi unsur penting yang dalam pembentukan pola kehidupan masyarakat. Konsep pendidikan akhlak, moral, etika dan budi pekerti merupakan pendidikan yang selalu menjadi dasar, baik secara formal maupun non formal. Pendidikan karakter memiliki esensi dan makna yang sama dengan pendidikan moral dan pendidikan akhlak. Tujuannya adalah membentuk pribadi anak, supaya menjadi manusia yang baik, warga masyarakat, dan warga Negara yang baik. Kementerian Pendidikan Nasional Indonesia telah merumuskan delapan belas nilai-nilai yang ditanamkan dalam diri warga Indonesia, khususnya siswa, dalam upaya membangun dan menguatkan karakter bangsa. Salah satu dari delapan belas nilai karakter tersebut yaitu kerja keras. Pendidik harus mampu mendesain untuk mewujudkan atau membentuk peserta didik menjadi pribadi yang memiliki karakter kerja keras melalui pembelajaran.
\end{abstract}

Kata Kunci: Pembelajaran, Karakter, Kerja keras.

\section{A. Pendahuluan}

Berbicara tentang karakter sesungguhnya karakter merupakan pilar penting dalam kehidupan bangsa dan negara. Ia ibarat kemudi dalam kehidupan. Namun dalam kenyatannya, perhatian terhadap karakter yang begitu pentingnya tidak di perhatikan dengan baik bahkan boleh dibilang terabaikan. Inti pendidikan karakter bukanlah sekadar mengajarkan pengetahuan kepada peserta didik tentang mana yang baik dan mana yang buruk. Namun lebih dari itu, pendidikan karakter merupakan proses menanamkan nilai-nilai positif kepada peserta didik melalui berbagai cara yang tepat. Pendidikan karakter yang menjadi isu utama dunia pendidikan saat ini sebenarnya bukan sesuatu yang baru. Latar belakang menghangatnya isu pendidikan karakter adalah harapan tentang pemenuhan sumber daya manusia yang berkualitas yang lahir dari pendidikan. Dengan demikian, penanaman pendidikan karakter sudah tidak dapat ditawar untuk diabaikan, terutama pada pembelajaran di sekolah, di samping lingkungan keluarga dan masyarakat.

Adapun kriteria manusia-manusia yang baik, warga masyarakat yang baik, dan warga Negara yang baik bagi suatu masyarakat atau bangsa, secara umum adalah nilai-nilai sosial tertentu yang banyak dipengaruhi oleh budaya masyarakat dan bangsanya. Dengan demikian, hakikat dari pendidikan karakter dalam konteks pendidikan di Indonesia adalah pendidikan nilai, yakni pendidikan nilai-nilai luhur yang bersumber dari budaya bangsa sendiri, dalam rangka membina kepribadian generasi muda.

Secara umum, nilai-nilai karakter atau budi pekerti ini menggambarkan sikap dan perilaku dalam hubungan dengan Tuhan, diri sendiri, masyarakat dan alam sekitar. Mengutip dari pendapatnya Lickona (1991), "pendidikan karakter 
secara psikologis harus mencakup dimensi penalaran berlandasan moral (moral reasoning), perasaan berlandasan moral (moral behaviour). Dalam rangka memperkuat pelaksanaan pendidikan karakter, ada delapan belas nilai-nilai dalam pengembangan pendidikan budaya dan karakter bangsa yang dibuat oleh Kementerian Pendidikan Nasional Indonesia yaitu religius, jujur, toleransi, disiplin, kerja keras, kreatif, mandiri, demokratis, rasa ingin tahu, semangat kebangsaan, cinta tanah air, menghargai prestasi, bersahabat/komunikatif, cinta damai, gemar membaca, peduli lingkungan, peduli sosial dan tanggungjawab. Dalam tulisan ini pembahasan mengenai nilai-nilai pengembangan pendidikan budaya dan karakter bangsa dibatasi hanya karakter kerja keras dalam strategi pembelajaran.

\section{B. Pembahasan \\ 1. Strategi}

Strategi digunakan untuk memperoleh kesuksesan atau keberhasilan dalam mencapai tujuan. Dalam dunia pendidikan strategi diartikan sebagai " $a$ plan, method or series of activities designed to achieves a particular educational goal" (J.R David, 1976). Dengan demikian pembelajaran dapat diartikan sebagai suatu perencanaan yang berisi tentang rangkaian kegiatan yang didesain untuk mencapai tujuan pendidikan tertentu. ${ }^{1}$

Ada dua hal yang perlu kita cermati dalam strategi pembelajaran. Pertama, strategi pembelajaran merupakan rancangan tindakan (rangkaian kegiatan) termasuk rancangan penggunaan metode dan pemanfaatan berbagai sumberdaya/ kekuatan dalam pembelajaran. Ini berarti penyusunan suatu strategi baru sampai pada proses penyusunan rencana kerja

\footnotetext{
${ }^{1}$ Wina Sanjaya. 2008. Kurikulum dan Pembelajaran: Jakarta. hal: 293
}

belum sampai pada tindakan. Kedua, strategi disusun untuk mencapai tujuan tertentu. Artinya arah dari semua keputusan penyusunan strategi adalah pencapaian tujuan. Dengan demikian, penyusunan langkah-langkah pembelajaran, pemanfaatan berbagai fasilitas dan sumber belajar semuanya diarahkan dalam upaya pencapaian tujuan. Oleh sebab itu, sebelum menentukan strategi perlu dirumuskan tujuan yang jelas, yang dapat diukur keberhasilannya, sebab tujuan adalah rohnya dalam implementasi suatu strategi. Tidak semua tujuan dapat dicapai hanya dengan satu strategi saja.

\section{Pembelajaran}

Konsep 'pembelajaran' tidak sama persis dengan konsep 'belajar' meski keduanya mempunyai kaitan yang cukup erat. Belajar merupakan aktivitas subjek didik untuk mendapatkan informasi, pengetahuan dan pengalaman. Sedangkan pembelajaran merupakan aktivitas interaktif dan terstruktur antara pendidik dan peserta didik untuk mencapai suatu perubahan. Tentu saja perubahan yang diharapkan adalah perubahan yang lebih positif, bukan negatif.

Istilah pembelajaran sebenarnya digunakan untuk menegaskan bahwa interaksi belajar, terutama di kelas, antar pendidik dan peserta didik itu bersifat dinamis. Istilah ini juga sekaligus dimaksudkan untuk menyempurnakan istilah pengajaran yang lebih menekankan pada peran aktif pendidik semata, sedangkan peserta didik cenderung menerima begitu saja apa yang telah disampaikan oleh si pendidik. Pembelajaran sangat menekankan proses interaksi dan pemanfaatan sumber-sumber belajar secara optimal. $^{2}$

${ }^{2}$ Muhamad Iksan, M. Sayuti, dkk. 2006. Pendidikan Kewarganegaraan Untuk SMTA, Majelis Pendidikan Dasar dan Menengah Pimpinan Pusat Muhammadiyah: Jakarta. h. 7-8 


\section{Pendidikan Karakter}

Dalam Kamus Besar Bahasa Indonesia, Pendidikan berasal dari dua suku kata yaitu " $d i$ " dan "dik". Lalu kata ini mendapat awalan kata "pe" dan akhiran "an" sehingga menjadi "pendidikan". Artinya "proses pengubahan sikap dan tata laku seseorang atau kelompok orang dalam usaha mendewasakan manusia melalui upaya pengajaran dan pelatihan. proses, cara, perbuatan mendidik."3

Pendidikan dikenal juga dengan istilah pedagogie. Menurut Abu Ahmadi dan Nur Uhbiyati, istilah ini berasal dari bahasa Yunani. Paedagogike adalah kata majemuk yang terdiri dari kata "paes" yang berarti "anak" dan kata "Ago" yang berarti "aku membimbing." Jadi Pedagogike berarti aku membimbing anak. Orang yang memiliki pekerjaan membimbing anak dengan maksud membawanya ke tempat belajar, dalam bahasa Yunani disebut "Pedagogos." Menurut Abu Ahmadi dan Nur Uhbiyati, jika kata ini diartikan secara simbolis, maka perbuatan membimbing seperti di atas itu, merupakan inti perbuatan mendidik yang tugasnya hanya untuk membimbing saja, dan kemudian pada suatu saat harus melepaskan anak itu kembali ke masyarakat. ${ }^{4}$

Menurut McLeod, sebagaimana dikutip oleh Muhibbin Syah, dalam bahasa Inggris, education (pendidikan) berasal dari kata educate (mendidik) artinya memberi peningkatan (to elicit, to give rise to), dan mengembangkan (to evolve, to develop). Dalam pengertian yang sempit, education atau pendidikan berarti

${ }^{3}$ Pusat Bahasa Departemen Pendidikan Nasional, KBBI (Kamus Besar Bahasa Indonesia), h. 330 .

${ }^{4} \mathrm{Abu}$ Ahmadi dan Nur Uhbiyati, Ilmu Pendidikan, (Jakarta: PT Rineka Cipta, 2003), Cet. ke-2, h. 70. perbuatan atau proses perbuatan untuk memperoleh pengetahuan. ${ }^{5}$

Menurut John Dewey sebagaimana dikutip oleh Yunus, pendidikan adalah suatu proses pembaharuan makna pengalaman, hal ini mungkin terjadi dalam pergaulan biasa atau pergaulan orang dewasa dengan orang muda, mungkin pula terjadi secara sengaja dan dilembagakan untuk menghasilkan kesinambungan sosial. Proses ini melibatkan pengawasan dan perkembangan dari orang yang belum dewasa dan kelompok dimana ia hidup. ${ }^{6}$

Karakter berasal dari bahasa Yunani kharakter yang berakar dari diksi 'kharassein' yang berarti memahat atau mengukir (to incribe/to engrave), sedang dalam bahasa Latin, karakter bermakna membedakan tanda. ${ }^{7}$ Dalam kamus Inggris-Indonesia, John M. Echols dan Hassan Shadily menyebutkan bahwa karakter berasal dari bahasa Inggris yaitu character yang berarti watak, karakter atau sifat. $^{8}$

E. Mulyasa dalam bukunya Manajemen Pendidikan Karakter mengutip Edward Wynne sebagai berikut: Karakter berasal dari Bahasa Yunani yang berarti "to mark" (menandai) dan memfokuskan pada bagaimana menerapkan nilai-nilai kebaikan dalam tindakan nyata atau perilaku sehari-hari. Oleh sebab itu, seseorang yang berperilaku tidak jujur, curang, kejam dan rakus dikatakan sebagai orang yang memiliki karakter jelek, sedangkan yang berperilaku baik, jujur,

${ }^{5}$ Muhibbin Syah, Psikologi Pendidikan, (Bandung: Remaja Rosdakarya, 1995), Cet. ke-2, h. 10.

${ }^{6}$ Yunus, Filsafat Pendidikan, (Bandung: Citra Sarana Grafika, 1999), h. 7.

${ }^{7}$ Sri Narwanti, Pendidikan Karakter, (Yogyakarta: Familia, 2011), Cet. ke. I, h. 1.

${ }^{8}$ John M. Echols dan Hassan Shadly, Kamus Inggris-Indonesia, (Jakarta: PT. Gramedia, 2006), h. 107. 
dan suka menolong dikatakan sebagai orang yang memiliki karakter baik/mulia. ${ }^{9}$

Doni Koesoema mengutip Sjarkawi, menyatakan bahwa karakter juga sering diasosiasikan dengan istilah apa yang disebut dengan temperamen yang lebih memberi penekanan pada definisi psikososial (pemahaman seorang individu atas situasi sosial di lingkungannya) yang dihubungkan dengan pendidikan dan konteks lingkungan. Sedangkan karakter dilihat dari sudut pandang behaviorial lebih menekankan pada unsur somatopsikis (penyakit fisik yang disebabkan oleh kejiwaan) yang dimiliki seseorang sejak lahir. ${ }^{10}$

Elfindri dkk mengartikan karakter sebagai sifat-sifat kejiwaan, akhlak, atau budi pekerti yang membedakan seseorang dengan orang lain. ${ }^{11}$ Kemudian Elfindri dkk mengklasifikasikan karakter pada empat bagian; karakter lemah, karakter kuat, karakter jelek dan karakter baik. Masing-masing dapat dilihat dengan indikator karakter sebagai berikut: ${ }^{12}$

1. Karakter lemah dapat ditemukan seperti; penakut, tidak berani mengambil resiko, pemalas, cepat kalah, dan beberapa jenis lainnya.

2. Karakter kuat dapat ditemukan seperti; tangguh, ulet, mempunyai daya juang yang kuat serta pantang mengalah.

3. Karakter jelek, misalnya; licik, egois, serakah, sombong, tinggi hati, pamer, suka ambil muka, dan sebagainya.

4. Karakter baik, misalnya; jujur, terpercaya, rendah hati, amanah dan sebagainya.

${ }^{9}$ H. E. Mulyasa, Manajemen Pendidikan Karakter, (Jakarta: Bumi Aksara, 2011), Cet. Ke-I, h. 3

${ }^{10}$ Doni Koesoema A, Pendidik Karakter Strategi Mendidik Anak di Zaman Global, (Jakarta: Grasindo, 2007), Cet. ke-1, h. 80.

${ }^{11}$ Elfindri dkk, Pendidikan Karakter Kerangka, Metode, dan Aplikasi untuk Pendidik dan Profesional, (Jakarta: Baduose Media, 2012), Cet. ke-I, h. 27.

${ }^{12}$ Ibid., h. 28
Dengan melihat klasifikasi dan
indikator di atas, Elfindri dkk menyimpulkan bahwa karakter anak yang diharapkan adalah karakter yang kuat dan baik. Kualitas mental atau kekuatan moral, akhlak atau budi pekerti yang merupakan kepribadian khusus yang harus melekat. ${ }^{13}$

Menurut Doni Koesoema, pendidikan karakter dapat dipahami sebagai sebuah usaha manusia untuk menjadikan dirinya sebagai manusia yang berkeutamaan. Manusia menambahkan sebuah keutamaan dalam dirinya ketika ia mampu menyempurnakan diri menjadi semakin lebih baik. Hasil-hasil usaha ini dapat dilihat melalui perilaku dan keputusannya. ${ }^{14}$ Pendidikan karakter merupakan hasil dari usaha manusia dalam mengembangkan dirinya sendiri. Manusia yang tadinya tidak memiliki karakter, melalui pelatihan lantas memiliki kualitas tambahan yang disebut kemampuan untuk berbuat baik, bertanggungjawab dan lainlain. ${ }^{15}$

Dalam pengertian sederhana, menurut Muclas Samani dan Hariyanto, pendidikan karakter adalah hal positif apa saja yang dilakukan guru dan berpengaruh kepada siswa yang diajarnya. Muclas Samani dan Hariyanto mengutip Winton bahwa pendidikan karakter adalah upaya sadar dan sungguh-sungguh dari seorang guru untuk mengajarkan nilai-nilai kepada para siswanya. Pendidikan karakter telah menjadi sebuah pergerakan pendidikan yang mendukung pengembangan sosial, pengembangan emosional, dan pengembangan etik para siswa. Merupakan suatu upaya proaktif yang dilakukan baik oleh sekolah maupun pemerintah untuk membantu siswa untuk mengembangkan inti pokok dari nilai-nilai etik dan nilainilai kinerja, seperti kepedulian, kejujuran, kerajinan, sportifitas, keuletan dan

\footnotetext{
${ }^{13}$ Ibid., h. 28.

${ }^{14}$ Doni Koesoema A, Pendidik Karakter Strategi Mendidik Anak di Zaman Global, (Jakarta: Grasindo, 2007), Cet. ke-I, h. 81.

${ }^{15}$ Ibid., h. 82.
} 
ketabahan, tanggung jawab, menghargai diri sendiri dan orang lain. ${ }^{16}$

\section{Karakter Kerja Keras}

Kerja keras merupakan tindakan yang menunjukan perilaku tertib dan patuh pada berbagai ketentuan dan peraturan. Makna kerja keras menurut (Totok Tasmara: 2000) bahwa aktivitasnya dilakukan karena dorongan untuk mewujudkan sesuatu, sehingga tumbuh rasa tanggung jawab yang besar. Sedangkan makna kerja keras, dalam konteks ini, secara terminologi adalah aktivitas atau kegiatan yang dilakukannya dikerjakan secara sungguh-sungguh. Selain itu, menurut J. Echols \& H Shadily (2003) makna kerja keras bagi guru adalah seorang (guru) pendidik yang memiliki optimisme dalam melakukan tugasnya. Artinya bahwa di dalam melaksanakan tugas mengajar dan mendidik seorang guru hendaknya memiliki motivasi yang kuat sehingga dapat memperoleh prestasi yang baik. Lebih lanjut, makna optimisme adalah keyakinan atas segala sesuatu dari segi yang baik atau positif dan menyenangkan atau suatu sikap yang selalu mempunyai harapan baik di segala hal. Jadi makna kerja keras adalah suatu sikap, kepribadian, watak, karakter, dan keyakinan yang kuat terhadap suatu kegiatan, dan dilakukannya secara sungguh-sungguh sehingga dapat memperoleh prestasi atau hasil yang baik.

Menurut (Dharma Kesuma, dkk 2011:17) kerja keras adalah suatu istilah yang melingkupi suatu upaya yang terus dilakukan (tidak pernah menyerah) dalam menyelesaikan pekerjaan/yang menjadi tugasnya sampai tuntas. Kerja keras bukan berarti bekerja sampai tuntas lalu berhenti, istilah yang kami maksud adalah mengarah pada visi besar yang harus dicapai untuk kebaikan/kemlasahatan manusia (umat) dan lingkungannya.

\footnotetext{
${ }^{16}$ Muchlas Samani dan Hariyanto, Konsep dan Model Pendidikan Karakter, h. 43.
}

Agus Wuryanto (2011) kerja keras indikatornya: menyelesaikan semua tugas dengan baik dan tepat waktu, tidak putus asa dalam menghadapi masalah, dan tidak mudah menyerah dalam menghadapi masalah. Kegiatan pembelajaran yang mengintegrasikan nilai karakter kerja keras, meliputi: (a) menyelesaikan tugas di dalam kelas, tugas pekerjaan rumah, tugas terstruktur, (b) menyelesaikan tugas sesuai batas waktu yang ditetapkan, (c) menyelesaikan tugas proyek, (d) tidak berhenti menyelesaikan masalah sebelum selesai, (e) melakukan tanya jawab berkaitan materi mata pelajaran dan keterkaitan dengan persoalan kontekstual dengan nilai kerja keras.

\section{Karakter Kerja Keras Perspektif Al- Qur'an}

Sebagai kitab suci, al-Qur'an menjadi panduan bagi ummat Islam. Dalam al-Qur'an tidak secara spesifik membahas tentang karakter kerja keras, namun al-Qur'an sebagai Kitab Hidayah (petunjuk) bagi manusia, penjelasan alQur'an mencakup petunjuk pada segala aspek lini kehidupan. Maka bisa dipastikan al-Qur'an memberikan isyarat-isyarat penting tentang karakter kerja keras. ${ }^{17}$

Penjelasan al-Qur'an tentang karakter kerja keras dapat kita pahami dalam ayat:

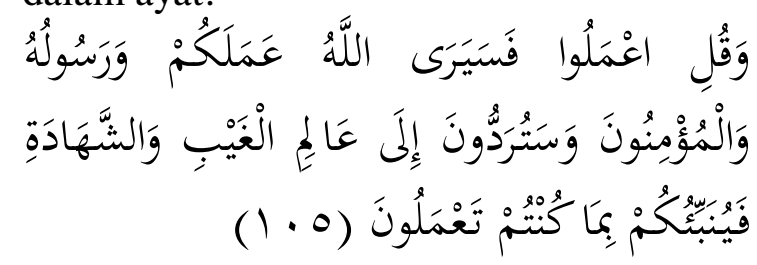

Dan Katakanlah: "Bekerjalah kamu, maka Allah dan Rasul-Nya serta orang-orang mukmin akan melihat pekerjaanmu itu, dan kamu akan dikembalikan kepada (Allah) Yang Mengetahui akan yang ghaib dan yang nyata, lalu diberitakan-Nya kepada

${ }^{17}$ Lajnah Pentashihan Mushaf al-Qur'an Badan Litbang dan Diklat Kementerian Agama RI, Kerja dan Ketenagakerjaan (Tafsir Al-Qur'an Tematik), (Jakarta: Aku Bisa, 2012), h. 126. 
kamu apa yang telah kamu kerjakan. (atTaubah/9: 105)

M. Quraish Shihab dalam tafsirnya menerangkan bahwa, kata waqul i'maluu diartikan katakanlah bekerjalah kamu karena Allah semata dengan aneka amal shaleh dan bermanfaat, baik untuk diri kamu maupun untuk orang lain atau masyarakat umum. Fasayarallau, yang artinya maka Allah akan melihat, yakni menilai dan memberi ganjaran amal perbuatan kamu. Dan Rasul-Nya serta orang-orang mukmin akan melihat dan menilainya juga, kemudian menyesuaikan perlakuan mereka dengan amal-amal kamu itu dan selanjutnya kamu akan dikembalikan kepada Allah melalui kematian wa satyradduuna ila 'alimil ghaibi wasyahadah, artinya, yang Maha Mengetahui yang ghaib dan yang nyata, lalu diberitahukan kepada kamu sanksi dan ganjaran atas apa yang telah kamu kerjakan, baik yang nampak ke permukaan maupun yang kamu sembunyikan dalam hati. ${ }^{18}$ Setelah penyampaian harapan tentang pengampunan Allah SWT, ayat tersebut melanjutkan dengan perintah untuk beramal yang shaleh.

Dalam ayat ini al-Qur'an memotivasi kaum muslimin untuk senantiasa beramal, berkreasi, dan berinovasi. Bahkan, Islam memberi nilai yang lebih esensial, yakni sebuah kerja keras seharusnya dilandasi atas niat yang benar, serta sadar bahwa prestasi kerjanya akan dinilai oleh Allah, Rasul dan umat mukmin, sebagaimana ditunjukkan oleh kata i'maluu yang berasal dari 'amila-ya'malu- 'amalan. ${ }^{19}$

Islam juga memberi apresiasi yang sama antara laki-laki dan perempuan melalui prestasi kerjanya, seperti dalam firman-Nya:

${ }^{18}$ M. Quraish Shihab, Tafsir Al-Misbah: Pesan, Kesan dan Keserasian Al-Qur'an, (Jakarta: Lentera Hati, 2006), Jil. V, hlm.711.

${ }^{19}$ al-Asfahani Al-Ragib, Mu'jam Mufrodat al-Fadhil al-Qur'an, (Lebanon: Dar AlKotob Alilmiyah, 2008). h. 347, pada term 'amila.

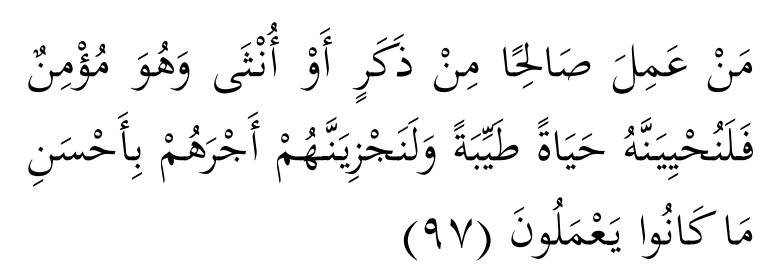

Barangsiapa yang mengerjakan amal saleh, baik laki-laki maupun perempuan dalam keadaan beriman, maka sesungguhnya akan Kami berikan kepadanya kehidupan yang baik dan sesungguhnya akan Kami beri balasan kepada mereka dengan pahala yang lebih baik dari apa yang telah mereka kerjakan. (an-Nahl/16:97)

Kata tayyib berarti sesuatu yang baik dan menyenangkan. Artinya setiap orang memiliki kesempatan yang sama asalkan bekerja secara sungguh-sungguh, baik laki-laki maupun perempuan, untuk mendapatkan kehidupan yang baik dan menyenangkan. Hanya saja, ukuran kehidupan yang tayyib tersebut bukan sekedar dilihat dari perolehan-perolehan yang bersifat duniawi. Namun hal yang terpenting adalah bagaimana mereka mampu menerima dengan penuh keridhaan dan keikhlasan atas bagaian rezeki yang telah ditetapkan oleh Allah, dan mampu mensyukuri setiap nikmat yang dianugerahkan Allah meski bersifat nonmateri, seperti kesehatan, kesempatan hidup, ketenangan batin, dan sebagainya. ${ }^{20}$

Disamping itu, bekerja keras juga menjadi ciri seorang muslim yang dicintai Allah, sebagaimana dalam hadits:

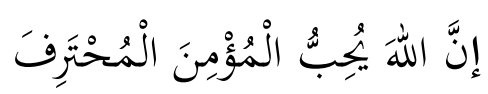

Sesungguhnya Allah mencintai seorang Mukmin yang giat bekerja. (HR. Baihaqi) $^{21}$

Hadits ini secara jelas memberikan apresiasi kepada setiap muslim yang bekerja dan berusaha. Islam sangat

\footnotetext{
${ }^{20}$ Ibn 'Asyur, al-Tahrir wat-Tanwir, (alMaktabah asy-Syamilah), jilid 8, h. 124.

${ }^{21}$ Riwayat al-Baihaqi, dalam kitab as-Sunan al-Kubra lil-Baihaqi, Juz 3.
} 
membenci umatnya yang hanya berpangku tangan menunggu belas kasihan orang lain. Islam tidak pernah membatasi bentuk pekerjaan seseorang, yang penting halal. Islam juga tidak pernah mengukur kualitas pekerjaan dan hasilnya, tetapi dari sisi kontinuitasnya, seperti dalam sebuah hadits:

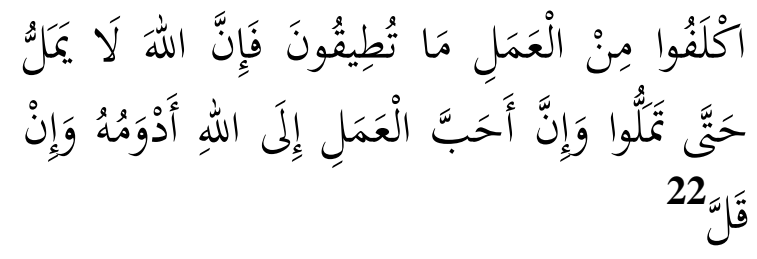

Bekerjalah semaksimal yang kamu bisa lakukan. Karena sesungguhnya Allah tidak akan bosan sehingga engkau menjadi bosan. Dan sesungguhnya amal yang paling Allah sukai ialah yang terusmenerus dikerjakan walaupun sedikit. (HR. Abu Dawud dari 'A'isyah).

Rasulullah mengajarkan kepada umatnya untuk tidak tergesa-gesa dalam mencapai apa yang diinginkan. Sebab nilai sebuah pekerjaan bukan dilihat dari hasilnya semata, namun kemudian tidak ada keberlanjutannya, akan tetapi yang bisa berjalan secara kontinu meski hasilnya tidak terlalu besar. Disinilah perlunya sebuah perencanaan yang matang, disamping bekerja keras. Karena itu, kerja santai, tanpa rencana, malas, pemborosan tenaga dan waktu adalah bertentangan dengan nilai Islam. ${ }^{23}$

\section{Kesimpulan}

Berdasarkan uraian yang telah disampaikan di atas mengenai Strategi Pembelajaran Karakter Kerja Keras maka dapat dinyatakan bahwa pengertian pendidikan karakter banyak ditawarkan

${ }^{22} \mathrm{Abu}$ Daud. Sunan Abi Daud. (Mesir: Maktabah Syarikah wa Matba'ah alMusthafa, 1952). kitab at-talawwu', bab maa yu'maru bihi minal qasd, No. 1161.

${ }^{23}$ Lajnah Pentashihan Mushaf al-Qurean Badan Litbang dan Diklat Kementerian Agama RI, Kerja dan Ketenagakerjaan (Tafsir Al-Qur'an Tematik), (Jakarta: Aku Bisa, 2012), h. 134. oleh para ahli, namun penulis cenderung kepada definisi pendidikan karakter yang menyatakan bahwa pendidikan karakter memiliki esensi dan makna yang sama dengan pendidikan moral dan pendidikan akhlak. Tujuannya adalah membentuk pribadi anak, supaya menjadi manusia yang baik, warga masyarakat, dan warga Negara yang baik. Adapun kriteria manusia-manusia yang baik, warga masyarakat yang baik, dan warga Negara yang baik bagi suatu masyarakat atau bangsa, secara umum adalah nilai-nilai sosial tertentu yang banyak dipengaruhi oleh budaya masyarakat dan bangsanya. Dengan demikian, hakikat dari pendidikan karakter kerja keras dalam konteks pendidikan di Indonesia adalah pendidikan nilai, yakni pendidikan nilai-nilai luhur yang bersumber dari budaya bangsa sendiri, dalam rangka membina kepribadian generasi muda.

\section{DAFTAR PUSTAKA}

Abu Daud. Sunan Abi Daud. (Mesir: Maktabah Syarikah wa Matba'ah alMusthafa, 1952).

A, Doni Koesoema. Pendidik Karakter Strategi Mendidik Anak di Zaman Global, (Jakarta: Grasindo, 2007).

Ahmadi, Abu dan Nur Uhbiyati. Ilmu Pendidikan, (Jakarta: PT Rineka Cipta, 2003).

al-Asfahani Al-Ragib, Mu'jam Mufrodat al-Fadhil al-Qur'an, (Lebanon: Dar AlKotob Al-ilmiyah, 2008).

Amin, Maswardi Muhammad. Pendidikan Karakter Anak Bangsa, (Jakarta: Baduose, 2011).

Amri, Sofan dkk. Implementasi Pendidikan Karakter Dalam Pembelajaran, (Jakarta: Prestasi Pustaka, 2011).

Arifin, Anwar. Memahami Paradigma Baru Pendidikan Nasional, (Jakarta: Ditjen Kelembagaan Agama Islam Depag, 2003). 
Badan Penelitian dan Pengembangan Pusat Kurikulum dan Perbukuan KEMDIKNAS, Pedoman Pelaksanaan Pendidikan Karakter, (Jakarta: Puskurbuk, 2011).

Character First, dikutip dan diterjemahkan oleh Muchlas Samani dan Hariyanto, Konsep dan Model Pendidikan Karakter.

Elfindri dkk, Pendidikan Karakter Kerangka, Metode, dan Aplikasi untuk Pendidik dan Profesional, (Jakarta: Baduose Media, 2012).

Ibn 'Asyur, al-Tahrir wat-Tanwir, (alMaktabah asy-Syamilah), jilid 8

Kementrian Pendidikan Nasional 2009, dikutip oleh Muchlas Samani dan Hariyanto, Konsep dan Model Pendidikan Karakter.

Lajnah Pentashihan Mushaf al-Qur "an Badan Litbang dan Diklat Kementerian Agama RI, Kerja dan Ketenagakerjaan (Tafsir Al-Qur'an Tematik), (Jakarta: Aku Bisa, 2012)

Majid, Abdul dan Dian Andayani. Pendidikan Karakter Prespektif Islam, (Bandung: Rosda Karya, 2012).

Masjkoery, Qohar dkk. Pendidikan Agam Islam, (Jakarta: Gunadarma, 2003).

Muchlas Samani dan Hariyanto, Konsep dan Model Pendidikan Karakter, (Bandung: PT Remaja Rosdakarya, 2011).

Mudyaharjo, Redja. Pengantar Pendidikan, (Jakarta: PT Rajagrafindo Persada, 2008).

Mulyasa, H. E. Manajemen Pendidikan Karakter, (Jakarta: Bumi Aksara, 2011).

Mulyasa, H. E. Manajemen Pendidikan Karakter, (Jakarta: Bumi Aksara, 2011).

Muslich, Masnur. Pendidikan Karakter, Menjawab Tantangan Krisis
Multidimensional, (Jakarta: Bumi Aksara, 2011).

M. Quraish Shihab, Tafsir Al-Misbah: Pesan, Kesan dan Keserasian AlQur'an, (Jakarta: Lentera Hati, 2006) Narwanti, Sri. Pendidikan Karakter, (Yogyakarta: Familia, 2011).

Nuh, Muhammad. Kerangka Acuan Pendidikan Karakter Tahun Anggaran 2010, (Jakarta: Direktorat Jenderal Pendidikan Tinggi Kementerian Pendidikan Nasiona, 2010).

Prayitno dan Belferik Manullang, Pendidikan Karakter dalam Pembangunan Bangsa, (Jakarta: PT Grasindo, 2011).

Pusat Bahasa Departemen Pendidikan Nasional, KBBI (Kamus Besar Bahasa Indonesia), (Jakarta: Pusat Bahasa, 2008).

Ramadhan, Syahrul. Kamus Ilmiah Populer, (Surabaya: Khazanah Media Ilmu, 2010).

Said Hamid Hasan dkk, Pengembangan Pendidikan Budaya dan Karakter Bangsa, (Jakarta: BPP Puskur Kemdiknas, 2010).

Syah. Muhibbin. Psikologi Pendidikan, (Bandung: Remaja Rosdakarya, 1995.

Wina Sanjaya. 2008. Kurikulum dan Pembelajaran. (Jakarta: Kencana).

Wuryanto, Agus. 2011. "Panduan Guru: Pendidikan Karakter Terintegrasi dalam Pembelajaran Matematika SMP”.

Yunus, Filsafat Pendidikan, (Bandung: Citra Sarana Grafika, 1999). 
Model Pembelajaran Kooperatif Perspektif Al-Qur'an

Rausyan Fikr. Vol. 15 No.1 Maret 2019. ISSN. 1979-0074 e-ISSN. 9772580594187 | 96 